\title{
Preweaning milk replacer intake and effects on long-term productivity of dairy calves
}

\author{
F. Soberon, E. Raffrenato, R. W. Everett, ${ }^{1}$ and M. E. Van Amburgh ${ }^{2}$ \\ Department of Animal Science, Cornell University, Ithaca, NY 14853
}

\begin{abstract}
The preweaning management of dairy calves over the last $30 \mathrm{yr}$ has focused on mortality, early weaning, and rumen development. Recent studies suggest that nutrient intake from milk or milk replacer during the preweaning period alters the phenotypic expression for milk yield. The objective of this study was to investigate the relationship between nutrient intake from milk replacer and pre- and postweaning growth rate with lactation performance in the Cornell dairy herd and a commercial dairy farm. The analysis was conducted using traditional 305-d first-lactation milk yield and residual lactation yield estimates from a test-day model (TDM) to analyze the lactation records over multiple lactations. The overall objective of the calf nutrition program in both herds was to double the birth weight of calves by weaning through increased milk replacer and starter intake. First-lactation 305-d milk yield and residuals from the TDM were generated from 1,244 and 624 heifers from the Cornell herd and from the commercial farm, respectively. The TDM was used to generate lactation residuals after accounting for the effects of test day, calving season, days in milk, days pregnant, lactation number, and year. In addition, lactation residuals were generated for cattle with multiple lactations to determine if the effect of preweaning nutrition could be associated with lifetime milk yield. Factors such as preweaning average daily gain (ADG), energy intake from milk replacer as a multiple of maintenance, and other growth outcomes and management variables were regressed on TDM milk yield data. In the Cornell herd, preweaning $\mathrm{ADG}$, ranged from 0.10 to $1.58 \mathrm{~kg}$, and was significantly correlated with first-lactation yield; for every $1 \mathrm{~kg}$ of preweaning ADG, heifers, on average, produced $850 \mathrm{~kg}$ more milk during their first lactation and $235 \mathrm{~kg}$ more milk for every Mcal of metabolizable energy intake above maintenance. In the commercial herd, for every $1 \mathrm{~kg}$ of preweaning ADG, milk yield
\end{abstract}

\footnotetext{
Received March 24, 2011.

Accepted October 5, 2011.

${ }^{1}$ Deceased.

${ }^{2}$ Corresponding author: mev1@cornell.edu
}

increased by $1,113 \mathrm{~kg}$ in the first lactation and further, every $1 \mathrm{~kg}$ of prepubertal ADG was associated with a $3,281 \mathrm{~kg}$ increase in first-lactation milk yield. Among the 2 herds, preweaning ADG accounted for $22 \%$ of the variation in first-lactation milk yield as analyzed with the TDM. These results indicate that increased growth rate before weaning results in some form of epigenetic programming that is yet to be understood, but has positive effects on lactation milk yield. This analysis identifies nutrition and management of the preweaned calf as major environmental factors influencing the expression of the genetic capacity of the animal for milk yield.

Key words: calf nutrition, milk production, test-day model, epigenetics

\section{INTRODUCTION}

Calf management programs have traditionally focused on strategies that restrict the amount of milk or milk replacer offered to the calf, to encourage grain intake in an effort to accelerate weaning, reduce the potential for scours and other illness, and reduce the cost of feeding and management (Kertz et al., 1979; Otterby and Linn, 1981; Anderson et al., 1987). However, evaluation of calf management data suggest that strategies that decrease liquid feed intake to enhance starter intake and promote rumen development have not significantly reduced any of those variables (Davis and Drackley, 1998; NAHMS, 2002, 2007).

More recent studies comparing the effects of suckling, controlled intakes, and ad libitum feeding of calves from birth up to $56 \mathrm{~d}$ of life have found that increasing the nutrient intake before $56 \mathrm{~d}$ of life from milk resulted in increased milk yield during the first lactation, ranging from 450 to $1,300 \mathrm{~kg}$ compared with the milk yield of restricted-fed calves during the same period (Foldager and Krohn, 1994; Bar-Peled et al., 1997; Shamay et al., 2005; Terré et al., 2009; Moallem et al., 2010). Two other studies that used milk replacer showed no significant effect of level of nutrient intake preweaning on first-lactation milk yield (Morrison et al., 2009; Raeth-Knight et al., 2009). However, the study of Raeth-Knight et al. (2009) potentially lacks sensitivity in determining 
milk yield differences because it is difficult to separate effects of herd, season, DIM, days pregnant, and other environmental factors among farms, given that calves were returned to several farms for measurement of milk yield differences. Overall, the sum of this data suggests epigenetic events occur during the preweaning period that alter the milk yield potential of the calf and these events are associated with enhanced nutrient intake from milk or milk replacer before weaning.

The concept of a lactocrine hypothesis has been recently introduced and describes the effect of milk-borne factors, including colostrum in this definition, on the epigenetic development of specific tissues or physiological functions (Bartol et al., 2008). Conceptually this topic is not new but the terminology is useful and the ability of several groups to make a direct connection from a milk-borne factor to a developmental function at the tissue or organ level is significant (Nusser and Frawley, 1997; Bagnell et al., 2005). Data relating to this topic has been described and discussed by others in neonatal pigs (Donovan and Odle, 1994; Burrin et al., 1997) and calves (Baumrucker and Blum, 1993; Blum and Hammon, 2000; Rauprich et al., 2000). The implication of this hypothesis and these observations are that the neonate can be programmed maternally and postnatally to alter development of a particular process and, based on the observations in calves, it is not well understood if the lactation response is a function of total nutrient intake or if factors in whole milk are responsible for the enhanced milk yield. In a recent study (Moallem et al., 2010), the effects of preweaning nutrition on first-lactation milk yield were associated with the type and quality of nutrients fed. Moallem et al. (2010) observed $10.3 \%$ higher milk yields during first lactation from heifers fed whole milk ad libitum compared with heifers fed milk replacer ad libitum during the same period and suggested that milk replacer did not contain the same biologically active factors as milk and, thus, did not impart any lactocrine effects on the calves. Because a large percentage of calves in the United States are fed milk replacer (NAHMS, 2007), the question remains whether enhancing growth through increased intake of milk replacer can also support changes in lactation milk yield. If so, then factors like protein and energy intake are more important for the neonate than growth factors or peptides found in whole milk (Grosvenor et al., 1993; Meisel, 2005).

The analysis of first lactation and subsequent lactation performance of large numbers of calves and heifers in prospective studies starting in early life is difficult and few studies have been able to capture enough data to make reasonable conclusions (Reid et al., 1964; Van Amburgh et al., 1998). Further, analyses of herd level data over time and among herds to evaluate early life nutrition and management effects might require more rigorous mathematical approaches similar to those used to generate heritability and predicted transmitting ability of genetic traits. An approach using a test-day model (TDM; Everett, 1994) has been used to evaluate extended lactations (Van Amburgh et al., 1997), first-lactation milk response to prepubertal ADG (Van Amburgh et al., 1998), and bST responses in commercial herds (Bauman et al., 1999). Extending this approach to the effects of calf growth and management on lactation milk yield seems logical. This approach should result in the least biased evaluation of the data, as variation in performance over time could obscure the changes in lactation yield due to early life management for the same reasons that unadjusted mixed model analyses of 305-d milk yield over time does not generate accurate predicted transmitting ability and heritability values for traits.

The objective of this study was to investigate the relationship between preweaning nutrient intake from milk replacer and future milk yield using standard 305-d milk yields and with a mathematical approach used to conduct genetic evaluations within and among herds. Another objective was to determine what factors during the early rearing period have an effect on lifetime performance of dairy calves.

\section{MATERIALS AND METHODS}

Calf growth, nutrition, and management data were collected from the records of 2 New York dairy farms, the Cornell Teaching and Research dairy herd and a family-owned commercial dairy farm near Watertown, NY. Both herds used similar milk replacers and due to the management strategies on each farm, have useful, but different growth measurements for calves and heifers that allowed us to partition the effects of nutrition, management, and stage of growth on milk yield differently. In this study, all calves on both farms were managed in a similar manner without a traditional control and treatment. Accordingly, the mathematical approach for generating data to evaluate milk yield effects was similar to that used to estimate heritability and predicted transmitting ability, where generally, no controls and treatments exist, but rather within-herd comparisons of production among contemporaries and the variability among individuals within the herd observed.

The preweaning growth objective in the Cornell herd was to double the birth weight by $60 \mathrm{~d}$ of age and to achieve that, milk replacer solids were fed at $1.5 \%$ of birth weight for the first $7 \mathrm{~d}$ of life and then 2 to $2.5 \%$ of birth weight from d 8 to 42 on a DM basis, diluted to $15 \%$ DM for feeding. Within the Cornell herd, birth 
weight, birth height, weaning weight, weaning height, age at first calving (AFC), and monthly average ambient temperatures were collected; ADG preweaning was calculated from birth and weaning weights. Further, in the Cornell herd, milk replacer intake was monitored and recorded, and that information was available and used in this analysis. Weaning from milk replacer in the Cornell herd was achieved by approximately $49 \mathrm{~d}$ by restricting milk replacer to $50 \%$ of prior intake for 7 $\mathrm{d}$ and feeding once per day in the evening. Calves were held in hutches or a calf barn for another 7 to $10 \mathrm{~d}$ and fed starter grain only until they were moved to group housing. The milk replacers used during the period of these observations were both commercially available $28 \% \mathrm{CP}$ and were either 15 or $20 \%$ fat (Excelerate; $28 \%$ CP, $15 \%$ fat, 4.65 Mcal of ME/kg; Milk Specialties Inc., Carpentersville, IL or Cows Match; $28 \%$ CP, $20 \%$ fat, 4.87 Mcal of ME/kg; Land O'Lakes Animal Milk Products Inc., Shoreview, MN), respectively. Calves were offered the same total of milk replacer solids throughout the year and no adjustments were made to accommodate the change in maintenance requirements due to changes in ambient temperature. Over the preweaning period, the calves consumed between 4.5 and $5.3 \mathrm{Mcal}$ of $\mathrm{ME} / \mathrm{d}$ from the milk replacers as estimated by the NRC (2001). The starter grain was a commercially available starter that was $23 \% \mathrm{CP}, 1.84$ Mcal/kg (Cargill Animal Nutrition, Minneapolis, MN) and was offered free choice starting at approximately d 5 of life. Starter grain intakes were not recorded and the implications of this will be discussed. Water was offered free choice with some exceptions during winter months, when it was offered for 4 to $5 \mathrm{~h}$ per day due to freezing conditions. Monthly average ambient temperature data was used with the calf BW information to estimate the daily maintenance requirements of calves (NRC, 2001) and this data was further used to estimate intake energy above maintenance from milk replacer before weaning for all of the calves in the data set. This allowed us to generate correlations between energy intake above maintenance from milk replacer with milk yield of the same animal once they completed a lactation and this provided an additional parameter to evaluate the effect of early life milk replacer nutrient intake on future milk yield. Growth data were collected starting in 1998 and the lactation data collection was through 2008.

The records from the Cornell herd were reviewed and any calf that was recorded as having diarrhea or treated with antibiotics was documented and categorical variables were designated for statistical evaluation of the effect of either or both of these outcomes on milk yield. Based on the available records and farm protocols, it was assumed that the majority of antibiotic treatment was primarily given for signs of respiratory illness.
On the commercial farm, birth weights, weaning weights, breeding weights, and AFC data were collected; preweaning ADG and ADG until breeding were calculated from the data. A standard calf feeding protocol existed on the dairy and the average milk replacer feeding rate was $0.9 \mathrm{~kg}$ per day from $\mathrm{d} 7$ to weaning at approximately $49 \mathrm{~d}$. The milk replacer used during the period of these observations was $28 \% \mathrm{CP}$ and $15 \%$ fat (Excelerate; Milk Specialties Inc.; 4.65 Mcal of ME/ $\mathrm{kg}$ ). Given the feeding rates and milk replacer composition, the calves were offered approximately 4.2 Mcal of $\mathrm{ME} / \mathrm{d}$ over the preweaning period (NRC, 2001). The starter grain was a commercially available $20 \% \mathrm{CP}$ starter (DM basis). Health data were not available from the commercial dairy herd.

Milk production and milk composition records were collected for both farms through DHI (Dairy Records Management System, Raleigh, NC) and analyzed either as actual 305-d milk yield or with the TDM. For the Cornell herd, 1,244 completed first-lactation records were available for analyses that covered $7 \mathrm{yr}$ of lactation data from 2001 to 2008. The lactation data from the commercial dairy covered the calendar years 1999 to 2004 and, after editing for missing data, resulted in 623 complete first-lactation records. In addition, due to the length of time the data covered, we were able to collect lactation records of animals that had completed up to 3 lactations, allowing us to evaluate the effect of preweaning nutrient intake on lifetime milk yield. The Cornell herd had 826 and 450 cattle with completed second and third lactations, respectively. For the commercial dairy, 484 and 271 second and third completed lactations were analyzed, respectively. Reasons for culling and other management factors were not analyzed.

\section{Test-Day Model}

Due to potential effects of calving year, season, management, and environment on lactation performance, a linear model that describes the biology of those influences was applied to the production data (Everett and Schmitz, 1994; Van Amburgh et al., 1997; Bauman et al., 1999). The TDM assumes that it is inappropriate to compare animals among farms without considering the management conditions within herd over time. Residuals from the TDM are simultaneously adjusted for herd test day, age, DIM, calendar month fresh, pregnancy, and management effects. Test-day residuals include the random genetic cow effects and treatment effects. The model accommodates the fact that conditions vary from herd to herd as well as from environment to environment and conditions change over time within herd. The TDM estimates within-herd, biological effects such 
as age, DIM, and stage of pregnancy. The model used to describe milk, fat, or protein on test day was

$$
Y_{i j k l m n o}=t_{i}+a_{j k}+d_{j l}+f_{j m}+c_{j n}+e_{i j k l m n o},
$$

where $Y_{i j k l m n o}=$ the dependent, continuous variable; $t_{i}$ $=$ the $i$ th test day observed for a herd; $a_{j k}=$ the $k$ th age in months for the oth observation, where $j=1,2$ divides the herd data into halves, the oldest data having separate fixed effects solutions from the newest data; $d_{j l}$ $=$ the $l$ th DIM for the test day of the oth observation, where $l$ describes the $10-\mathrm{d}$ intervals and ranges from 1 to 45 for the first and second-and-greater lactations; $f_{j m}$ $=$ the $m$ th month of freshening associated with the oth observation; $c_{j n}=$ the $n$th day pregnant, where $n=1$ is the first 5 mo of pregnancy, $n=2$ is the sixth month, . $\ldots$, and $n=5$ for the ninth-and-greater months of pregnancy for the first and second lactations; and $e_{i j k l m n o}=$ the residual for the oth observation of a cow in the $n$th period of pregnancy, the $m$ th month fresh, the lth DIM, and the $k$ th age in months in the jth period and tested on the $i$ th herd test day.

The observation $\mathbf{y}$ is a vector of all milk, fat, or protein observations for a cow and the elements of $\mathbf{y}$ are assumed to be correlated. The fixed effects equations for the linear model are

$$
x^{\prime} \mathbf{R}^{-1} x \beta=x^{\prime} \mathbf{R}^{-1} \mathbf{y},
$$

where $\mathbf{R}$ describes the relationships among the test-day observations in the $\mathbf{y}$ vector on a cow; $x$ is an incidence matrix describing the test days, age, and DIM for each record on each cow; $\beta$ is a vector of solutions that are of primary interest; and $x^{\prime}$ is a partial residual estimate. If a cow is tested $n$ times, $\mathbf{R}$ is an $n \times n$ matrix describing the residual variance-covariance structure of the $n$ test days for the cow; $\mathbf{R}$ is assumed to have an autocorrelation structure such that $\mathbf{R} / \sigma^{2}=\rho$ is an autocorrelation matrix, where $\sigma^{2}$ is the variance of the associated testday data, and $\rho_{i j}$ is the correlation between tests $i$ and $j$ and equals

$$
\rho^{q} \text { and } q=\left|\left(t_{i}-t_{j}\right) / 30\right|,
$$

where $t_{i}$ and $t_{j}$ are DIM for test $i$ and $j$, respectively, and $\rho=0.73,0.58$, and 0.69 for milk yield, fat yield, and protein yield, respectively. The model was fit to the data and residuals were obtained as $e=y-x^{\prime} \beta$. The residuals were standardized to a common variance for all test days.

Test-day residuals were combined to produce TDM residual lactation records, which were used in the analysis to determine the effect of preweaning and pre- pubertal nutrition of calves and heifers on subsequent lactation production. Because the residuals are from a grand mean, the values will be both positive and negative and the difference between residuals is the variable of interest. We are making the assumption that most of the test-day residuals are associated with either unexplained variation after the adjustments described above or to genetic relationships among the variable of interest, which was also evaluated.

\section{Statistical Analysis}

Each farm was analyzed separately due to the environmental conditions specific to the farm that would influence both growth and the lactation milk yields. After the TDM residual lactation data were generated, the residuals were regressed on the measured growth and intake variables from each herd. Factors analyzed on both farms included preweaning ADG, birth weight, weaning weight, AFC, birth year, birth month, and season of birth. For the Cornell herd, 305-d milk yield and TDM lactation residuals were also regressed on calculated ME intake from milk replacer above maintenance from milk replacer. Linear, cubic, and quadratic relationships among the measured intake and growth variables and TDM residuals were conducted using a generalized linear model procedure as well as mixed model procedures within SAS 9.2 (SAS Institute Inc., Cary, NC). For all data, cubic and quadratic relationships were nonsignificant and were dropped from the analyses.

To analyze the 305-d milk yield, the statistical models differed due to the calf and heifer growth data available from each farm. For the Cornell herd, the model used was

$$
Y_{i j}=S_{i}+G_{j}+E_{i j}
$$

where $Y_{i j}$ is the dependent, continuous variable; $S_{i}=$ the effect of year of calving; $G_{j}=$ the ADG of the calf before weaning; and $E_{i j}=$ the residual error of the $i$ th year of calving and the $j$ th average daily gain.

A separate model was used to evaluate energy intake above maintenance:

$$
Y_{i j}=I E_{i}+E_{i j},
$$

where $Y_{i j}$ is the dependent, continuous variable; $I E_{i}$ $=$ the intake energy above maintenance from milk replacer of the calf before weaning; and $E_{i j}=$ the residual error of the $i$ th year of calving and the $j$ th intake energy above maintenance.

For the commercial dairy, the model used was 
Table 1. Growth, performance, and yield parameters from each farm used in the analyses of lactation performance ${ }^{1}$

\begin{tabular}{|c|c|c|c|c|}
\hline Parameter & $\begin{array}{l}\text { Cornell } \\
\text { herd }^{2}\end{array}$ & SD & $\begin{array}{l}\text { Commercial } \\
\text { herd }\end{array}$ & SD \\
\hline First-lactation records $(\mathrm{n})$ & 1,244 & & 623 & \\
\hline Birth weight $(\mathrm{kg})$ & 41.68 & 5.09 & 42.55 & 5.10 \\
\hline Average monthly temperature $\left({ }^{\circ} \mathrm{C}\right)$ & 8.57 & 9.22 & 9.41 & 9.33 \\
\hline Average megacalories above maintenance from milk replacer (Mcal/d) & 2.81 & 0.61 & NA & NA \\
\hline Weaning weight $(\mathrm{kg})$ & 82.08 & 10.25 & 84.13 & 10.81 \\
\hline Average age at first calving (d) & 691 & 54 & 687 & 64 \\
\hline First-lactation 305 -d milk yield $(\mathrm{kg})$ & 10,899 & 1,781 & 13,583 & 1,285 \\
\hline
\end{tabular}

${ }^{1}$ Data are averages over the time period studied.

${ }^{2}$ In Harford, New York.

${ }^{3} \mathrm{NA}=$ not applicable.

$$
Y_{i j k}=S_{i}+G_{j}+P W_{k}+E_{i j k}
$$

where $Y_{i j k}$ is the dependent, continuous variable; $S_{i}=$ the effect of year of calving; $G_{j}=$ the ADG of the calf before weaning; $P W_{k}=$ the postweaning ADG; and $E_{i j k}$ $=$ the residual error of the $i$ th year of calving and the $j$ th preweaning ADG and $k$ th postweaning ADG.

In addition, data from the Cornell herd for calf diarrhea and antibiotic treatment were analyzed for the proportion of calves treated and then a mixed model analyses was conducted to determine the effect of either of these observations on the first-lactation milk yield and the interaction between ADG and milk yield. The relationship between energy intake above maintenance and diarrhea and antibiotic treatment for first-lactation milk yield was also analyzed by mixed model approaches.

Due to the availability of subsequent lactation data for the Cornell herd, regressions of preweaning ADG and intake over maintenance on TDM residual milk were also generated for the second and third lactation and cumulative milk from the first through third lactation. In the commercial herd, preweaning ADG, birthto-breeding ADG, and weaning-to-breeding ADG per animal was regressed on TDM residual milk yield for the second and third lactations and cumulative milk yield from the first through third lactation. Significance for all analyses was declared for $P<0.05$. Trends were declared at $P<0.10$.

\section{RESULTS AND DISCUSSION}

Data on birth weight, growth rate, AFC, milk yield, and other performance parameters for each herd are found in Table 1. The mean preweaning growth rates from the Cornell herd were $0.82 \pm 0.18 \mathrm{~kg} / \mathrm{d}$, with a range from 0.10 to $1.58 \mathrm{~kg} / \mathrm{d}$, and this was surprising, given the amount of milk replacer consumed by the calves. We believe this range in preweaning growth data reflects several factors. First, it demonstrates that although the calves are offered adequate nutrients above maintenance from milk replacer, the effects of cold and heat stress are present in the data set. Monthly average temperatures at the Cornell herd averaged $8.6^{\circ} \mathrm{C}$ and ranged from -9.0 to $21.9^{\circ} \mathrm{C}$. Further, no characterization of colostrum status was available and this has been shown to affect prepubertal ADG (Faber et al., 2005).

In the Cornell herd, the effect of diarrhea or antibiotic treatment on preweaning ADG was not significant and ADG differed by approximately $30 \mathrm{~g} / \mathrm{d}$ for calves that had either event in their records $(P>0.1)$. However, for calves that had both events recorded, preweaning ADG was lower by approximately $50 \mathrm{~g} / \mathrm{d}(P<0.01)$. Over the 8-yr period, approximately $59 \%$ of all of the calves had at least 1 of the recorded events.

On the commercial dairy, the observed preweaning ADG was similar in range and the mean was 0.66 $\pm 0.11 \mathrm{~kg}$, with a range from 0.32 to $1.27 \mathrm{~kg}$. These data most likely represent the reality of growth rates observed on most farms, assuming that environmental conditions and calf health challenges are reflected in the range.

On both farms, first-lactation milk yield was positively correlated with preweaning ADG and weaning weight $(P<0.03)$ and, in the Cornell herd, energy intake above maintenance from milk replacer and ambient temperature $(P<0.001$; Table 2$)$. Further, on the commercial farm, milk production was positively correlated with ADG from birth to breeding $(P<0.01)$ and from weaning to breeding $(P<0.1$; Table 2$)$. On the commercial farm ADG from birth to breeding and ADG from weaning to breeding were highly correlated with each other (correlation coefficient of $0.94 ; P<$ 0.01). On both farms, first-lactation milk yield was sig- 
Table 2. Equations developed from linear regression of the following preweaning and management parameters with first-lactation test-day model residuals from each farm

\begin{tabular}{|c|c|c|}
\hline Dependent variable & Derivation & $\begin{array}{l}\text { Significance } \\
(P \text {-value })\end{array}$ \\
\hline \multicolumn{3}{|l|}{ Cornell dairy (Harford, NY) } \\
\hline Birth weight $(\mathrm{kg})$ & $\mathrm{y}=-246.34-2.78 \mathrm{x}$ & 0.724 \\
\hline Weaning weight $(\mathrm{kg})$ & $\mathrm{y}=-1,354.38+15.05 \mathrm{x}$ & $<0.001$ \\
\hline Temperature at birth $\left({ }^{\circ} \mathrm{C}\right)$ & $\mathrm{y}=-331.76+23.80 \mathrm{x}$ & $<0.001$ \\
\hline Birth weight $(\mathrm{kg})$ & $\mathrm{y}=-794.84-19.63 \mathrm{x}$ & 0.07 \\
\hline Weaning weight (kg) & $\mathrm{y}=-1,237.60+15.32 \mathrm{x}$ & $<0.01$ \\
\hline ADG from birth to breeding (kg) & $\mathrm{y}=-2,985.00+3,280.55 \mathrm{x}$ & $<0.01$ \\
\hline ADG from weaning to breeding $(\mathrm{kg})$ & $\mathrm{y}=-1,061.46+1,168.48 \mathrm{x}$ & 0.10 \\
\hline
\end{tabular}

nificantly affected by season of birth and year of birth. Among both herds, AFC was also evaluated as a factor affecting first-lactation milk yield and found to be nonsignificant (data not shown; $P=0.59$ ).

Also, because culling is highly associated with low milk production, there was a concern that as multiple lactations were analyzed, some bias could be introduced by culling out lower-producing animals, thus influencing the multiple lactation information. The Cornell data set was analyzed to examine potential bias in the data from the cattle with second or third lactations because those animals were also within the first-lactation analyses. The TDM residuals for first-lactation cattle $(\mathrm{n}=1,244 ;$ mean $=-128.1 \mathrm{~kg})$ were compared with the first-lactation residuals for the cattle that completed second $(\mathrm{n}=826$; mean $=-143.5 \mathrm{~kg})$ and third $(\mathrm{n}=450 ;$ mean $=-171.4 \mathrm{~kg})$ lactations (Table 3$)$. The TDM residuals among the first lactation for all parity groups were not significantly different; thus, we concluded that no bias existed due to preferential culling in the analysis of multiparous cattle within this data set.

To make a direct comparison with other studies, the 305-d first-lactation milk yields from the Cornell herd were regressed on the preweaning growth rates of the calves and, in this analyses, for every kilogram of ADG before weaning, the 305-d milk yield increased by 704 $\mathrm{kg}$ in the first lactation $(P<0.01)$. This effect was linear within the data set and implied that, under the conditions of this analysis, the greater the ADG of the calf before weaning, the greater their potential firstlactation milk response, consistent with other studies (Shamay et al., 2005; Moallem et al., 2010).

Although the analyses of the 305-d first lactation milk yield resulted in identifying preweaning ADG as a factor affecting first-lactation milk yield, another approach was to use the TDM lactation milk yield residuals to evaluate the response. The use of the TDM analyses should be a less biased solution for milk yield. Accordingly, the TDM lactation yields were analyzed by regressing the residuals on preweaning ADG and, for every kilogram of ADG preweaning, heifers produced $850 \mathrm{~kg}$ more milk during their first lactation $(P<0.01$; Table 4). To ensure no bias in the response due to some genetic component, the milk response identified by the TDM was analyzed with the sire, dam, and individual predicted transmitting ability for milk and the relationships were nonsignificant, implying the increase in milk yield was environmental in nature and equally affected individuals of high and low genetic merit. As this appears to be an environmental response, calves and cattle on each farm could have different milk yield responses due to nutrition, housing, and other environmental factors. Therefore, analyzing animals on individual farms should demonstrate similar relationships if the effect is consistent, but the magnitude of the response might be different.

Table 3. Test-day model (TDM) milk residuals ( $\mathrm{kg}$ ) for cattle with 1, 2, or 3 completed lactations in the Cornell herd (Harford, NY) and the effect of preweaning ADG on each lactation milk yield

\begin{tabular}{|c|c|c|c|c|c|c|c|c|c|}
\hline Lactation & \multicolumn{3}{|c|}{ First lactation } & \multicolumn{3}{|c|}{ Second lactation } & \multicolumn{3}{|c|}{ Third lactation } \\
\hline First-second & 826 & -143.5 & 941.3 & 826 & 611.5 & 888.1 & & & \\
\hline First-third & 450 & -171.4 & $1,100.2$ & 450 & 892.8 & $1,131.1$ & 450 & 757.7 & 48.3 \\
\hline
\end{tabular}


Table 4. Differences in test-day model residual milk (kg) for first, second, and third lactation as well as cumulative milk from first through third lactation by ADG before weaning and the energy intake over predicted maintenance for calves in the Cornell (Harford, NY) herd ${ }^{1}$

\begin{tabular}{|c|c|c|c|c|c|}
\hline Lactation & $\begin{array}{c}\text { No. of } \\
\text { animals }\end{array}$ & $\begin{array}{l}\text { Predicted difference } \\
\text { in milk per } \\
\text { kilogram of } \\
\text { preweaning ADG }\end{array}$ & $P$-value & $\begin{array}{l}\text { Predicted difference } \\
\text { in milk by each } \\
\text { additional megacalorie } \\
\text { over maintenance } \\
\text { preweaning }^{2}\end{array}$ & $P$-value \\
\hline First & 1,244 & 849.63 & $<0.01$ & 235.42 & $<0.01$ \\
\hline Second & 826 & 888.08 & $<0.01$ & 108.39 & 0.26 \\
\hline Third & 450 & 48.32 & 0.91 & 351.39 & $<0.01$ \\
\hline First through third & 450 & $2,279.53$ & 0.01 & 902.76 & $<0.01$ \\
\hline
\end{tabular}

The same relationship between TDM milk yield and preweaning ADG was analyzed on the commercial farm and, for every kilogram of ADG preweaning, heifers produced $1,114 \mathrm{~kg}$ more milk during their first lactation $(P=0.03 ;$ Table 5$)$. Thus, on the commercial farm, the response was approximately $31 \%$ greater than for the Cornell dairy despite lower preweaning ADG, and was consistent with the difference in first-lactation milk yield differences between the 2 farms (Table 1 ). The average milk yield in the commercial herd was approximately $25 \%$ greater than in the Cornell herd over the period studied; thus, the calf response to early life nutrient intake is most likely associated with the overall management level applied to the lactating cattle in the dairy. When combining both farms and using a model that included farm and season of birth as class variables and birth weight as a covariate, for every additional kilogram of ADG preweaning, heifers produced $970 \mathrm{~kg}$ more milk during their first lactation $(P<0.01)$. The uniformity of this relationship over 1,867 lactations provides positive evidence that the preweaning period represents a time of opportunity to alter the set points of calves for potential lifetime milk production and is consistent with other data (Shamay et al., 2005; Moallem et al., 2010).
Moallem et al. (2010) fed both milk and milk replacer, and the calves fed milk replacer did not show a significant milk response, and they suggested that the effects observed were possibly due to bioactive factors in milk that did not exist in milk replacer. However, the response observed in the current study suggests that nutrient supply from high-quality milk replacer is effective at stimulating the milk yield response. Comparing the data from Moallem et al. (2010) with the current data would indicate that the digestibility, protein quality, and protein level of the milk replacer along with total energy intake appear to be critical to generate the milk response.

In the data from Cornell, first-lactation milk yield was not significantly affected by reported cases of diarrhea. However, calves receiving antibiotics had significantly decreased milk yield and produced $493 \mathrm{~kg}$ less milk in the first lactation $(P>0.01)$ than calves with no record of being treated. Regardless of antibiotic treatment, the effect of ADG on first-lactation milk yield was significant in all calves $(P<0.05)$. Calves treated with antibiotics produced $623 \mathrm{~kg}$ more milk per kilogram of preweaning ADG, whereas calves that did not receive antibiotics produced $1,407 \mathrm{~kg}$ more milk per kilogram of preweaning ADG. The effect of increased nutrient in-

Table 5. Differences in test-day model residual milk $(\mathrm{kg})$ for first, second, and third lactation as well as cumulative milk from first through third lactation by ADG before weaning and from weaning to breeding for the commercial herd

\begin{tabular}{|c|c|c|c|c|c|}
\hline Lactation & $\begin{array}{c}\text { No. of } \\
\text { animals }\end{array}$ & $\begin{array}{l}\text { Predicted difference } \\
\text { in milk per } \\
\text { kilogram of } \\
\text { preweaning ADG }\end{array}$ & $P$-value & $\begin{array}{l}\text { Predicted difference } \\
\text { in milk per } \\
\text { kilogram of ADG } \\
\text { from weaning } \\
\text { to breeding }\end{array}$ & $P$-value \\
\hline First & 623 & $1,113.97$ & 0.03 & $1,168.48$ & 0.10 \\
\hline Second & 484 & -526.44 & 0.49 & $2,719.87$ & 0.01 \\
\hline Third & 271 & $1,293.47$ & 0.18 & $2,874.88$ & 0.05 \\
\hline First through third & 271 & $1,286.18$ & 0.51 & $8,199.80$ & $<0.01$ \\
\hline
\end{tabular}


take from milk replacer was still apparent in the calves that were treated, but the milk yield response was most likely attenuated due to factors associated with sickness and nutrient partitioning away from growth functions (Johnson, 1998; Dantzer, 2006).

In this data set, we had the opportunity to evaluate the effect of preweaning ADG on milk production in the second and third lactations. Data from both herds demonstrated positive relationships between preweaning ADG and milk yield in subsequent lactations (Tables 4 and 5). In the Cornell herd, the effect was significant for the second lactation, positive but nonsignificant for the third lactation, and when analyzed over the 3 lactations, highly significant and substantial in the amount of milk represented by preweaning ADG. In the commercial herd, the data were only significant for the first lactation and the negative residuals in the second lactation could not be explained by any variables that were available in the data set. Overall the data were positive over the 3 lactations in the commercial herd, although not significant. This demonstrates that the effect of early life nutrient intake can be variable by herd and the variation within herd is difficult to identify when measuring this response over multiple lactations. However, the data strongly suggest that the effect of early life nutrition and management previously attributed only to the first lactation can now be discussed in terms of lifetime productivity.

The ADG of the calves were responsive to the environment, especially under conditions of cold stress, and maintenance requirements of the calves increased during periods of cold stress. Thus, at constant feeding rates, despite being higher than industry averages, growth rate and first-lactation milk yield were decreased by the average ambient temperature at birth, representing changes in maintenance requirements (Figures 1 and 2).

Among these 2 farms, calves born during the winter produced, on average, $556 \mathrm{~kg}$ less milk during their first lactation than calves born during the summer $(P<0.01$; data not shown). Thus, the season in which a calf was born reflected the effects of environmental temperature on the maintenance requirements of the calves. However, specific local environments at each farm interacted differently; at the Cornell farm, calves born during the summer produced more milk than calves born during any other season $(P<0.01)$, whereas at the commercial farm, calves born during the fall produced more milk than calves born during any other season $(P<0.01)$. We assume these observations are related to energy intake above maintenance; however, we cannot rule out the effects of photoperiod or differences in colostrum status of calves in explaining some of the milk response (Rius and Dahl, 2006).

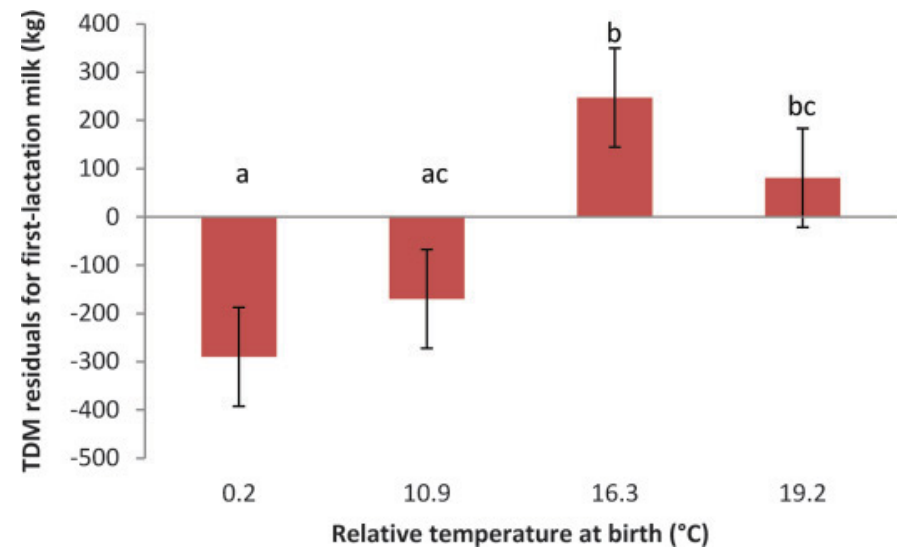

Figure 1. Test-day model (TDM) lactation residuals in kilograms of milk $( \pm \mathrm{SD})$, averaged by temperature at the time of birth, in the Cornell (Harford, NY) herd. Columns with different letters (a-c) differ $(P<0.05)$. Color version available in the online PDF.

To explore this in a different manner and make the data more quantifiable, the growth data and milk yield were analyzed using temperature at birth. Within the Cornell dairy, calves born during the colder months $\left(0.2^{\circ} \mathrm{C}\right)$ produced $532.2 \mathrm{~kg}$ less milk than calves born in thermoneutral conditions $\left(16.3^{\circ} \mathrm{C} ; P<0.01\right.$; Figure $1)$. Because all calves were fed the same amount of milk replacer throughout the year, we concluded that the effect of ADG on first-lactation milk production was an indirect effect of nutrient intake above maintenance during the first $49 \mathrm{~d}$ of life. To quantify this relationship, information regarding the milk replacer offered to each calf during the first $49 \mathrm{~d}$ of life and mean monthly temperatures for the time they were born were recorded. To evaluate the effect of intake over maintenance as another variable affecting first-lactation milk yield, the

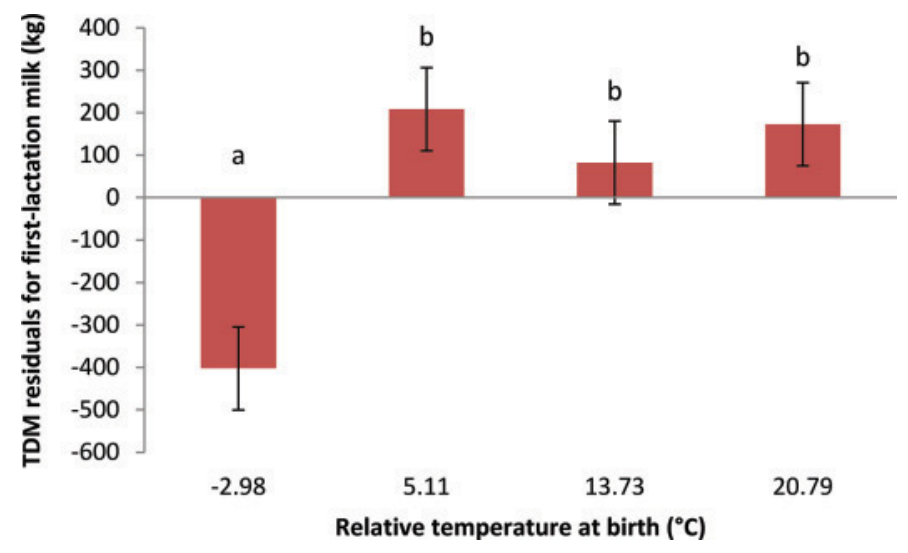

Figure 2. Test-day model (TDM) lactation residuals in kilograms of milk ( $\pm \mathrm{SD})$, averaged by temperature at the time of birth, in the commercial herd. Columns with different letters $(\mathrm{a}, \mathrm{b})$ differ $(P<$ 0.05). Color version available in the online PDF. 
2001 Dairy NRC equation (NRC, 2001) for maintenance requirements for calves was used to calculate the megacalories of energy required for each calf and then the megacalories of energy consumed above maintenance were estimated. Using the calculated information on megacalories of energy consumed above maintenance, the TDM residuals were regressed on the megacalories of energy above maintenance. Within the Cornell herd, positive correlations with first-, second-, and thirdlactation milk yields were observed for megacalories of energy consumed above the maintenance requirements (Table 4). In the Cornell herd, for every megacalorie of additional energy consumed from milk replacer during the preweaning period, calves produced $235 \mathrm{~kg}$ more milk $(P<0.01)$ during the first lactation or a total of $903 \mathrm{~kg}$ more milk per megacalorie when analyzed over 3 lactations $(P<0.01)$. Calves born during the colder months $\left(0.2^{\circ} \mathrm{C}\right)$ consumed, on average, $1.43 \mathrm{Mcal} / \mathrm{d}$ less energy above maintenance than calves born during the warmer months $\left(19.2^{\circ} \mathrm{C}\right)$. Based on NRC calculations, this difference in energy above maintenance is equivalent to $0.3 \mathrm{~kg}$ of $\mathrm{ADG}$ and provides some indication of the sensitivity of calf to this input relative to the signals to enhance milk-producing ability. To evaluate the possible limits of these correlations, we analyzed the cubic and quadratic effects of megacalories above maintenance with milk yield. Within our data set, a linear equation best described this relationship, indicating that, within the range of data analyzed (ADG ranging from 0.10 to $1.58 \mathrm{~kg}$ and for megacalories above maintenance from 0.92 to $4.13 \mathrm{Mcal}$ ), no plateau occurred in the milk yield response. Also, when analyzed with the data for antibiotic treatment, the effect of intake over maintenance was not different between calves that were treated or not $(P>0.1)$.

Most of the data in the literature related to prepubertal ADG and future milk yield has demonstrated negative effects of increasing the level of nutrient intake in prepubertal heifers (Foldager and Sejrsen, 1987; Radcliff et al., 2000). However, in the current study, data from the commercial farm demonstrates that if the calves received a higher level of nutrient intake during the preweaning phase, higher levels of nutrient intake postweaning had a positive effect on first-lactation milk yield. In this data, for every additional kilogram of ADG from birth to breeding, heifers produced 3,281 $\mathrm{kg}$ of milk during their first lactation $(P<0.01$; Table $5)$ and this effect was observed over the 3 lactations. If only the postweaning period was considered, for every additional kilogram of ADG from weaning to breeding, heifers produced $8,200 \mathrm{~kg}$ of milk during 3 lactations $(P<0.01$; Table 5$)$. The primary difference between this data set and data generated previously is preweaning nutrition. In previous studies (Van Amburgh et al., 1998; Radcliff et al., 2000), heifers were started on treatment diets postweaning and no attempt was made to modify preweaning nutrition or management. The calves in this data set were fed a higher level of nutrient intake before weaning and this appears to have altered the prepubertal growth response, allowing heifers to be able to positively respond to higher levels of nutrient intake postweaning. Similar observations were described by Moallem et al. (2010) and data from Meyer et al. (2006) demonstrated that calves fed greater amounts of higher protein milk replacer before weaning had significantly greater bromodeoxyuridine incorporation and, thus, greater mammary parenchyma proliferation before weaning. Although mammary DNA is not a good indicator of future milk yield, the observation that cells exist in the neonatal mammary gland that are responsive to nutrient supply might provide a possible mechanism and area of study for these longterm responses.

These observations reinforce the role that management plays in phenotypic expression of genetic capacity. The observation that preweaning growth rate accounted for approximately $22 \%$ of the variation in first-lactation milk yield further indicates that the greater milk-producing capacity can be modified in these calves, once we more fully understand the signals that are being realized by this nutrient intake response. Based on the relationship between preweaning growth and milk yield, it might appear that any factors that enhance protein synthesis and thus, growth, will enhance the milk yield capacity of the calf. Therefore, to potentially stimulate this long-term response energy intake above maintenance and protein status of the calf become critical factors, but these effects were not directly analyzed within this study. This was implied in this study by the composition of milk replacer fed to the calves. The relationship between the protein status of the calf and future milk yield was suggested in the data of Moallem et al. (2010) where the calves fed the lower protein quality milk replacer compared with whole milk did not demonstrate a significant milk yield response despite being offered the milk replacer on an ad libitum basis. Further, this would be consistent with the requirements of calves, determined from serial harvest studies on young dairy calves, where protein requirements for higher gain would be between 26 and 28\% CP (Van Amburgh and Drackley, 2005; Bartlett et al., 2006).

Calf starter intake was not measured in this study and relative to energy intake is a shortcoming of the data with regard to the possible effect of this additional energy on milk yield. The role of starter intake could be important; however, it is hard to establish DMI from starter grain that provide adequate energy supply for 
optimum growth rates before $49 \mathrm{~d}$ of age, the period in which the calf appears to be sensitive to this effect, especially if consideration is given to absorbed energy substrates and not simply rumen development and gut fill (Stobo et al., 1966). Studies in calves fed restricted levels of milk replacer (10\% initial BW at $12.5 \%$ solids), evaluating starter grain formulation, DMI, and rumen development demonstrate growth rates over the first 5 wk of 0.18 to $0.35 \mathrm{~kg} / \mathrm{d}$ (Coverdale et al., 2004; Lesmeister and Heinrichs, 2004). Based on the data presented in the current paper, the growth rates observed in those studies would not stimulate the factors responsible for the enhanced milk yield response and, therefore, the absence of preweaning grain intake is most likely not confounding the relationships observed in this study.

These observations imply that the nutritional or metabolic programming that occurs during the first 2 mo of life has lifelong implications on milk production. Similarly, lifelong implications of a stimulus shortly after birth were traced to epigenetic changes in rats (Weaver et al., 2004). They demonstrated that the behavior of the mother affected the way her pups responded to stress throughout their life; these effects were mediated by epigenetic regulations. The observation that nutrition can impart epigenetic changes has gained considerable attention over the last few years in the area of human development and great progress has been made (Hanley et al., 2010). It appears that similar gains can be made in milk production through epigenetic effects that are modified through a lactocrine-type mechanism in the first 2 mo of life in the neonatal calf.

\section{CONCLUSIONS}

This analysis presents data that reinforces the observation that lifetime performance is influenced by early life development and dairy producers have the ability to manipulate this early life programming via nutrition. The length of time that heifer calves are responsive to the effects of nutrition warrants further investigation. However, we now know that this manipulation must start immediately after birth and continue for at least $5 \mathrm{wk}$ and must be in the form of liquid feed to have a positive influence on lifetime performance.

\section{ACKNOWLEDGMENTS}

We gratefully acknowledge Milk Specialties Global (Carpentersville, IL) and Land O'Lakes Inc. (St. Paul, MN) for financial and other support of this work, the New York dairy farm that provided us with access to the farm's data, and the staff of the Teaching and Research Farm (Harford, NY) for their help and support of this work. We also thank John Ferry, DVM (Adams, NY) for his help in securing a portion of this data.

\section{REFERENCES}

Anderson, K. L., T. G. Nagaraja, and J. L. Morrill. 1987. Rumen metabolic development in calves weaned conventionally or early. J. Dairy Sci. 70:1000-1005.

Bagnell, C. A., W. Yan, A. A. Wiley, and F. F. Bartol. 2005. Effects of relaxin on neonatal porcine uterine growth and development. Ann. N. Y. Acad. Sci. 1041:248-255.

Bar-Peled, U., B. Robinzon, E. Maltz, H. Tagari, Y. Folman, I. Bruckental, H. Voet, H. Gacitua, and A. R. Lehrer. 1997. Increased weight gain and effects on production parameters of Holstein heifer calves that were allowed to suckle from birth to six weeks of age. J. Dairy Sci. 80:2523-2528.

Bartlett, K. S., F. K. McKeith, M. J. VandeHaar, G. E. Dahl, and J. K. Drackley. 2006. Growth and body composition of dairy calves fed milk replacers containing different amounts of protein at two feeding rates. J. Anim. Sci. 84:1454-1467.

Bartol, F. F., A. A. Wiley, and C. A. Bagnell. 2008. Epigenetic programming of porcine endometrial function and the lactocrine hypothesis. Reprod. Domest. Anim. 43:273-279.

Bauman, D. E., R. W. Everett, W. H. Weiland, and R. J. Collier. 1999. Production responses to bovine somatotropin in Northeast dairy herds. J. Dairy Sci. 82:2564-2573.

Baumrucker, C. R., and J. W. Blum. 1993. Secretion of insulin-like growth factors in milk and their effect on the neonate. Livest. Prod. Sci. 35:49-72.

Blum, J. W., and H. Hammon. 2000. Colostrum effects on the gastrointestinal tract, and on nutritional, endocrine and metabolic parameters in neonatal calves. Livest. Prod. Sci. 66:151-159.

Burrin, D. G., T. A. Davis, S. Ebner, P. A. Schoknecht, M. L. Fiorotto, and P. J. Reeds. 1997. Colostrum enhances the nutritional stimulation of vital organ protein synthesis in neonatal pigs. J. Nutr. 127:1284-1289.

Coverdale, J. A., H. D. Tyler, J. D. Quigley III, and J. A. Brumm. 2004. Effect of various levels of forage and form of diet on rumen development and growth in calves. J. Dairy Sci. 87:2554-2562.

Dantzer, R. 2006. Cytokine, sickness behavior, and depression. Neurol. Clin. 24:441-460.

Davis, C. L., and J. K. Drackley. 1998. The Development, Nutrition, and Management of the Young Calf. Iowa State Univ. Press, Ames.

Donovan, S. M., and J. Odle. 1994. Growth factors in milk as mediators of infant development. Annu. Rev. Nutr. 14:147-167.

Everett, R. W. 1994. Method of bovine management. US Patent Number 5,351,644. Cornell Research Foundation (Ithaca, NY), assignee.

Everett, R. W., and F. Schmitz. 1994. Dairy genetics in 1994 and beyond. Cow and sire evaluation using test-day records, DairyGene, and DairyView for farm management. Pages 4-39 in Mimeo Ser. No. 170. Cornell Coop. Ext., Cornell Univ., Ithaca, NY.

Faber, S. N., N. E. Faber, T. C. McCauley, and R. L. Ax. 2005. Case study: Effects of colostrum ingestion on lactational performance. Prof. Anim. Sci. 21:420-425.

Foldager, J., and C. C. Krohn. 1994. Heifer calves reared on very high or normal levels of whole milk from birth to $6-8$ weeks of age and their subsequent milk production. Proc. Soc. Nutr. Physiol. $3: 301$.

Foldager, J., and K. Sejrsen. 1987. Mammary gland development and milk production in dairy cows in relation to feeding and hormone manipulation during rearing. Page 102 in Research in Cattle Production, Danish Status and Perspectives. Landhusholdningsselskabet, Frederiksberg, Denmark.

Grosvenor, C. E., M. F. Picciano, and C. R. Baumrucker. 1993. Hormones and growth factors in milk. Endocr. Rev. 14:710-728.

Hanley, B., J. Dijane, M. Fewtrell, A. Grynberg, S. Hummel, C. Junien, B. Koletzko, S. Lewis, H. Renz, M. Symonds, M. Gros, L. Harthoorn, K. Mace, F. Samuels, and E. M. van Der Beek. 2010. Metabolic imprinting, programming and epigenetics-A review of 
present priorities and future opportunities. Br. J. Nutr. 104(Suppl. 1):S1-S25.

Johnson, R. W. 1998. Immune and endocrine regulation of food intake in sick animals. Domest Anim. Endocrinol. 15:309-319.

Kertz, A. F., L. R. Prewitt, and J. P. Everett. 1979. An early weaning calf program: Summarization and review. J. Dairy Sci. 62:18351843.

Lesmeister, K. E., and A. J. Heinrichs. 2004. Effects of corn processing on growth characteristics, rumen development, and rumen parameters in neonatal dairy calves. J. Dairy Sci. 87:3439-3450.

Meisel, H. 2005. Biochemical properties of peptides encrypted in bovine milk proteins. Curr. Med. Chem. 12:1905-1919.

Meyer, M. J., A. V. Capuco, D. A. Ross, L. M. Lintault, and M. E. Van Amburgh. 2006. Developmental and nutritional regulation of the prepubertal bovine mammary gland: II. Epithelial cell proliferation, parenchymal accretion rate, and allometric growth. J. Dairy Sci. 89:4298-4304.

Moallem, U., D. Werner, H. Lehrer, M. Zachut, L. Livshitz, S. Yakoby, and A. Shamay. 2010. Long-term effects of ad libitum whole milk prior to weaning and prepubertal protein supplementation on skeletal growth rate and first-lactation milk production. J. Dairy Sci. 93:2639-2650.

Morrison, S. J., H. C. F. Wicks, R. J. Fallon, J. Twigge, L. E. R. Dawson, A. R. G. Wylie, and A. F. Carson. 2009. Effects of feeding level and protein content of milk replacer on the performance of dairy herd replacements. Animal 3:1570-1579.

NAHMS (National Animal Health Monitoring Service). 2002. Dairy 2002. Part I: Reference of dairy health and management in the United States. USDA-APHIS-VS. Accessed Mar. 23, 2011. http:// www.aphis.usda.gov/animal_health/nahms/dairy/downloads/ dairy02/Dairy02_dr_PartI.pdf.

NAHMS (National Animal Health Monitoring Service). 2007. Dairy 2007. Heifer calf health and management practices on U.S. dairy operations. USDA-APHIS-VS. Accessed Mar. 23, 2011. http:// www.aphis.usda.gov/animal_health/nahms/dairy/downloads/ dairy07/Dairy07_ir_CalfHealth.pdf.

NRC. 2001. Nutrient Requirements of Dairy Cattle. 7th rev. ed. National Academy Press, Washington, DC.

Nusser, K. D., and S. Frawley. 1997. Depriving neonatal rats of milk from early lactation has long-term consequences on mammotrope development. Endocrine 7:319-323.

Otterby, D. E., and J. G. Linn. 1981. Advances in nutrition and management of calves and heifers. J. Dairy Sci. 64:1365-1377.

Radcliff, R. P., M. J. Vandehaar, L. T. Chapin, T. E. Pilbeam, D. K. Beede, E. P. Stanisiewski, and H. A. Tucker. 2000. Effects of diet and injection of bovine somatotropin on prepubertal growth and first-lactation milk yields of Holstein cows. J. Dairy Sci. 83:23-29.
Raeth-Knight, M., H. Chester-Jones, S. Hayes, J. Linn, R. Larson, D. Ziegler, B. Ziegler, and N. Broadwater. 2009. Impact of conventional or intensive milk replacer programs on Holstein heifer performance through six months of age and during first lactation. J. Dairy Sci. 92:799-809.

Rauprich, A. B., H. M. Hammon, and J. W. Blum. 2000. Influence of feeding different amounts of first colostrum on metabolic, endocrine, and health status and on growth performance of neonatal calves. J. Anim. Sci. 78:896-908.

Reid, J. T., J. K. Loosli, G. W. Trimberger, K. L. Turk, S. A. Asdell, and S. E. Smith. 1964. Causes and prevention of reproductive failure in dairy cattle. IV. Effect of plane of nutrition during early life on growth, reproduction, production, health and longevity of Holstein cows. Birth to fifth calving. Cornell Research Bulletin 987. Cornell University, Ithaca, NY.

Rius, A. G., and G. E. Dahl. 2006. Exposure to long-day photoperiod prepubertally may increase milk yield in first-lactation cows. J. Dairy Sci. 89:2080-2083.

Shamay, A., D. Werner, U. Moallem, H. Barash, and I. Bruckental. 2005. Effect of nursing management and skeletal size at weaning on puberty, skeletal growth rate, and milk production during first lactation of dairy heifers. J. Dairy Sci. 88:1460-1469.

Stobo, I. J. F., J. H. B. Roy, and H. J. Gaston. 1966. Rumen development in the calf. 1. The effect of diets containing different proportions of concentrates to hay on rumen development. Br. J. Nutr. $20: 171-188$.

Terré, M., C. Tejero, and A. Bach. 2009. Long-term effects on heifer performance of an enhanced growth feeding programme applied during the pre-weaning period. J. Dairy Res. 76:331-339.

Van Amburgh, M. E., and J. K. Drackley. 2005 Current perspectives on the energy and protein requirements of the pre-weaned calf. Pages 67-82 in Calf and Heifer Rearing: Principles of Rearing the Modern Dairy Heifer From Calf to Calving. P. C. Garnsworthy, ed. Nottingham Univ. Press, Nottingham, UK.

Van Amburgh, M. E., D. M. Galton, D. E. Bauman, and R. W. Everett. 1997. Management and economics of extended calving intervals with use of bovine somatotropin. Livest. Prod. Sci. 50:15-28.

Van Amburgh, M. E., D. M. Galton, D. E. Bauman, R. W. Everett, D. G. Fox, L. E. Chase, and H. N. Erb. 1998. Effects of three prepubertal body growth rates on performance of Holstein heifers during first lactation. J. Dairy Sci. 81:527-538.

Weaver, I. C. G., N. Cervoni, F. A. Champagne, A. C. D'Alessio, S. Sharma, J. R. Seckl, S. Dymov, M. Szyf, and M. J. Meaney. 2004. Epigenetic programming by maternal behavior. Nat. Neurosci. $7: 847-854$. 